Applying knowledge management to project marketing in a demanding technology transfer project: convincing the customer across the knowledge gap

This is author's self-archive version. This is not equal to the final published version. The final article's DOI: https://doi.org/10.1016/j.indmarman.2008.12.008

Tuula Lehtimäki

University of Oulu, Faculty of Economics and Business Administration, P.O. BOX 4600, 90014 Finland

tuula.lehtimaki@oulu.fi

Henri Simula

Helsinki University of Technology, BIT Research Centre, P.O. BOX 5500, 02015 TKK, Finland

henri.simula@tkk.fi

Jari Salo

University of Oulu, Faculty of Economics and Business Administration, P.O. BOX 4600, 90014 Finland

jari.salo@oulu.fi

Date of submission: 1.2.2008, 26.5.2008 
Tuula Lehtimäki is a researcher and a doctoral candidate at the Department of Marketing at the University of Oulu. Her research interests include launch management, new product development, innovations, and KM.

Henri Simula is a researcher and a project manager at the BIT Research Centre and a doctoral candidate at the Department of Industrial Management at the Helsinki University of Technology. His personal research interests relate to new product management, commercialization of technology, and product innovation management.

Jari Salo is a Professor of Information and Communication Business at the University of Oulu. Salo has published in the Journal of Business and Industrial Marketing, the Business Process Management Journal, the Online Information Review, and the Journal of Euromarketing, among others. Present research interests include business relationship digitization, electronic commerce including mobile marketing and new product development and innovation. 


\title{
Applying knowledge management to project marketing in a demanding technology transfer project: convincing the customer across the knowledge gap
}

\begin{abstract}
Literature on project and knowledge management has examined knowledge management in projects, but the utilization of knowledge management in project marketing is still largely unexplored. This study examines the links between knowledge management and project marketing activities in a project where the seller wants to convince the potential buyer about a demanding investment project. An in-depth case study illustrates this in a situation hampered by a technical knowledge gap between the parties. The buyer is committed when they can trust the seller's capability to successfully accomplish the project. The seller must concretize and communicate its core and project-specific knowledge of technologies and customer needs through project marketing. A framework of and implications for knowledge management and project marketing activities in different project phases are presented. It is proposed that knowledge management is a pertinent tool for project marketing as it helps to understand the roles of different knowledge types.
\end{abstract}

Keywords: Buyer-seller relationship; Case study; Core knowledge; Customer commitment; Industrial products; Knowledge management; Project marketing; Project-specific knowledge; Process technology 


\section{Introduction}

This study focuses on knowledge management (KM) in the context of project marketing and examines how KM could be utilized in project marketing as a tool, in order to convince the customer to commit to the project and ultimately to sign the contract. The research on KM and project marketing form the basis of this study. KM has received considerable attention among academics and practitioners in recent years (Kakabadse, Kakabadse \& Kouzmin, 2003). KM research can be approached from a KM outcome perspective (creation, retention, and transfer of knowledge), and from the perspective of properties of the context of KM (unit, relationships between units, properties of the knowledge) (Argote, McEvily \& Reagans, 2003). Dominant perspectives of KM research are philosophy-based, cognitive, network, community, and quantum model (Kakabadse et al., 2003). This study is closest to the community model, which sees knowledge as a socially constructed and based on experience and concentrates on knowledge creation and application (Kakabadse et al., 2003).

KM literature discusses KM in projects to some degree (Disterer, 2002; Leseure \& Brookes, 2004). Also project management literature covers issues of $\mathrm{KM}$ in projects such as information management strategies in projects (Back \& Moreau, 2001), knowledge transfer (Adenfelt \& Lagerström, 2006; Snider \& Nissen, 2003), social practices in KM (Bresnen, Edelman, Newell, Scarbrough \& Swan, 2003; Brookes, Morton, Dainty \& Burns, 2006), project communication and implementation (Koskinen, 2004), and learning in projects (Reich, 2007). $\mathrm{KM}$ is challenging in a project environment due to many discontinuities in an organization and flows of personnel, materials, and information (Bresnen et al., 2003; Disterer, 2002). It has been found that despite the discontinuous nature of projects there is a need for continuous KM, because not all knowledge used in projects is one-off (Leseure \& Brookes, 
2004). However, KM in project organizations is still quite underdeveloped, even though systematic and effective KM would be needed in order to avoid knowledge fragmentation and loss of organizational learning (Kasvi, Vartiainen \& Hailikari, 2003).

Project marketing is interested in what happens before and after the request for tenders on a project (Boughton, 1987). Project marketing research is a young research discipline and has gained greater attention since the 1980s (Cova \& Salle, 2007). Project marketing streams covered in this study relate mainly to the relationship based view (Cova \& Hoskins, 1997; Cova, Mazet \& Salle, 1996; Skaates \& Tikkanen, 2003; Skaates, Tikkanen \& Lindblom, 2002), systems selling (Günter \& Bonaccorsi, 1996; Mattsson, 1973), and marketing of solutions (Cova \& Salle, 2007). Today project marketing research is considered to move from process-based research towards the interactions between people and projects (Leybourne, 2007), but currently there is no specific KM discussion related to project marketing, and this is where this study aims to contribute.

This study focuses on project marketing and $\mathrm{KM}$ at the buyer-seller relationship level of a single project. The specific project type in question concerns designing, testing, and delivering a technological process solution. Marketing activities in a buyer-seller relationship aiming at successful adoption and implementation of a technological process innovation have been investigated earlier to some extent (e.g. Athaide, Meyers \& Wilemon, 1996). The need for $\mathrm{KM}$ in project marketing is present especially in innovative projects, where the customer needs technical support and consultation in order to evaluate the validity and quality of a proposed project. The perceived risk of the customer is high, but the seller is also risking failure. The seller needs to externalize (Nonaka, 1994) and communicate the tacit technical and customer knowledge tied to individuals in the firm in order to convince the customer to 
risk the early adoption of innovative technology. It is also important that the seller is able to maintain a high level of satisfaction and commitment from the buyer throughout the whole project.

Hence, project management literature has discussed KM in projects, but the special challenges of KM related to project marketing have not been addressed. The purpose of this study is to examine how utilization of KM could support project marketing activities in an innovative customer project. This study proposes that $\mathrm{KM}$ could provide project marketing with enhanced success in the form of more committed and satisfied customers. For managers this study provides a framework on how to utilize KM for marketing planning and implementation in projects concerning complex customized technological solutions. The paper first builds on project marketing literature. Next, KM viewpoints are related to project marketing issues. An in-depth case study is presented to discuss the links between $\mathrm{KM}$ and project marketing in an innovative large-scale investment project between a technically knowledgeable seller and a less technically knowledgeable buyer. Finally empirically grounded conclusions are drawn along with implications for managers.

\section{The buyer-seller relationship view on project marketing of technical solutions}

The central project marketing characteristics identified in the literature are discontinuity, uniqueness, and complexity (Cova \& Ghauri, 1996; Mandják \& Veres, 1998; Tikkanen, 1998; Skaates, Tikkanen \& Alajoutsijärvi, 2003). Discontinuity provides special challenges for project marketing because marketing efforts are often aimed at single purchase situations even though a more long term relationship approach is also applied when possible (Hadjikhani, 1996). Uniqueness and complexity are especially related to large-scale investment projects 
including complex technical solutions, which are examined here. They are also discussed under systems selling (Mattsson, 1973) and marketing of solutions (Cova \& Salle, 2007). Solution can be defined as a combination of elements of the offer which will contribute to producing value for the customer (Cova \& Salle, 2007) and includes assumption of high a level of scale, scope, and the degree of integration of the elements of the offer (Galbraith, 2005).

A sales project begins with the search period, when project opportunities and relevant industry developments are identified, and continues until the project can be evaluated as a whole, knowledge is built for future offerings, and possibly additional services are supplied for the buyer (Cova \& Holstius, 1993). Project marketing does not focus on any single phase of a sales project. Moreover, attention to project marketing activities before, during and after the project is needed (Skaates et al., 2002). The project marketing process model, which has become relatively stable, has three large stages: the phase when a project does not yet exist, pre-tender, and tender preparations (Cova, Ghauri \& Salle, 2002; Cova \& Salle, 2007). As this model is widely used to present project marketing stages it is also utilized in this study.

Milieu, the firm's relationships to a local network of business and non-business actors, is considered as an important unit of analysis in project marketing (Cova et al., 1996). Outside the project marketing stream Athaide and colleagues have discussed relationship approach on the development and sale of complex process technologies (Athaide, Stump \& Joshi, 2003; Athaide et al., 1996; Athaide \& Stump, 1999; Stump, Athaide \& Joshi, 2002; Meyers \& Athaide, 1991). Athaide et al. (1996) discuss more thoroughly the buyer-seller interactions during the commercialization of technological process innovation. They examine the relationship marketing activities employed by successful sellers of high-tech process 
innovations, and they organize those activities into eight categories: product customization, information generation on product performance, product education/training, ongoing product support, proactive political involvement, product demonstration/trial, real-time problem solving assistance, and clarification of the product's relative advantage (Table 1).

(Take in: Table 1 Marketing activities in a buyer-seller relationship (Athaide et al., 1996).)

This study also focuses on marketing activities in a buyer-seller relationship in a similar context. Thus, those activities can be utilized here to discuss project marketing activities. In order to be able to conduct such activities it is important to manage externalization of tacit technical knowledge and utilization of both technical and customer knowledge. Next, the connection between $\mathrm{KM}$ and project marketing is discussed.

\section{Knowledge management and its reflections on project marketing}

The concept of knowledge is widely discussed in various disciplines, but the definition varies (e.g. Assudani, 2005; Nonaka \& Takeuchi, 1995). In this study knowledge is understood primarily as a resource, either as an input resource for some activity or as an output resource resulting from some activity (Assudani, 2005). Knowledge is traditionally categorized to tacit and explicit knowledge (Polanyi, 1966). Unlike explicit knowledge, tacit knowledge is hard to codify and it is tied to individuals (Polanyi, 1966). Knowledge is also tied to how individuals operate as a whole. In an innovative organization people work together to create something new: from a managerial perspective, the question is how to manage that individual knowledge efficiently in projects in order to satisfy customer needs (Probst, Raub \& Romhardt, 2000). 
Knowledge can be categorized by its contents or by its applicability in projects. Kasvi et al. (2003) describe project knowledge created in any R\&D project and they discuss technical, procedural and organizational knowledge. Technical knowledge concerns the product, its parts and technologies. Procedural knowledge concerns acting in a project and producing and using the product. Organizational knowledge concerns communication and collaboration. From these categories prior research has often discussed technical knowledge (e.g. Cohen \& Levinthal, 1990; Hänninen \& Kauranen, 2007), sometimes including other knowledge areas such as market knowledge (e.g. Verworn, 2006). Market knowledge is important to include in the relationship approach of this study. However, it is limited here to refer to only customer knowledge due to the study's focus on the buyer-seller relationship level. The objective is to learn how to apply project marketing in technically innovative and demanding customer projects and therefore two categories, customer, and technical knowledge, are utilized in this study.

Another distinction is made between project-specific temporal knowledge and the generally applicable core knowledge of the firm (Leseure \& Brookes, 2004). Core knowledge is constantly used and improved by project teams, but project-specific knowledge is useful for one project and has a low probability of being used again (Leseure \& Brookes, 2004). The technical and customer knowledge used in projects most likely includes both core and projectspecific knowledge. A seller must show that it has strong technical knowledge in general but at the same time they have to prove that this knowledge is also contributing towards the project the buyer is interested in. Likewise the seller has to concretize its core knowledge of customers, but especially it has to communicate a deep understanding on the needs and requirements of the specific buyer in question. This means that project marketing utilizes both core knowledge and created project-specific knowledge as a basis for its activities, and they, 
together with the technical and customer knowledge, form the knowledge categories of this study (Table 2).

(Take in: Table 2 Knowledge categorization utilized in this study.)

KM can be seen to include creating, retaining, and transferring knowledge (Argote et al., 2003; Kasvi et al., 2003). In addition, how knowledge is utilized is also important (Assudani, 2005; Kasvi et al., 2003). Systems selling and project marketing have special characteristics such as customized production, the high value of the single order, and differences in know-how between supplier and customer (Backhaus, 1995; Günter \& Bonaccorsi, 1996). These characteristics highlight the need for the creation of project-specific knowledge, which can be strongest during the diagnosis of customer problems, but can be present during the whole project (Meyers \& Athaide, 1991). In the situation of a single sale, a great deal of the created project-specific knowledge might not be directly applicable to other projects and that might negatively affect the seller's satisfaction with the relationship with the buyer, as the seller's efforts could be felt to outweigh the rewards (Stump et al., 2002). However, creating and communicating project-specific technical and customer knowledge is an important part of trust building in every project. Each project is unique in terms of the people involved, and technical or financial matters and trust-generating efforts must be tailored to each individual project (Skaates et al., 2003). Commitment and trust in a relationship increase when partners get to know each other over time (Gulati, 1995). Relationship length is naturally one of the key variables that have a direct impact on the knowledge level between parties (Stanko, Bonner \& Calantone, 2007). Perceived buyer knowledge has been found to affect a seller's satisfaction with the relationship (Athaide et al., 2003). Thus, both the seller's and the buyer's 
knowledge levels influence the relationship as well as selection of appropriate marketing activities.

The difficulty in transferring knowledge between organizations is well acknowledged (Argotea \& Ingramb, 2000). That forms part of the dilemma in this study, which centers on a seller striving to transfer knowledge from their organization to the buyer's organization. Knowledge transfer can happen via communications and training but also in terms of transfer of knowledge reservoirs (Argotea \& Ingramb, 2000). Knowledge must be transferred between a firm's internal units before it can be communicated to the customer. The boundaries between a project organization and the permanent organization make it difficult to transfer experiences and knowledge from projects to the permanent organization (Disterer, 2002). The transfer of knowledge created in projects is also hampered by the discontinuous nature of projects. Gathering of new knowledge from projects needs systematic and continuous attention (Leseure \& Brookes, 2004), but that is made difficult by less organized social practices that play an important role in the transfer of knowledge in project environments (Bresnen et al., 2003; Brooks et al., 2006).

Thus, gathering and retaining created knowledge in a managed way is problematic, as is the transfer of knowledge between units and organizations. KM must also consider how projectspecific knowledge, core knowledge, and different categories of knowledge should be managed so that they support the presented project marketing activities. Figure 1 captures the presented project marketing activities in relation to their appropriate project marketing phases, and links the KM process to a project marketing framework. Knowledge is utilized in project marketing for example when demonstrating technical capabilities or when educating the buyer. Knowledge transfer is a prerequisite for knowledge utilization and retention. New core and 
project-specific knowledge is created in projects both concerning technical and customer knowledge, and created core knowledge should be retained for future use.

(Take in: Figure 1 Linkages of KM to project marketing phases.)

\section{Methods}

The aim of this study is to develop preliminary new insights and a deeper understanding of the links between $\mathrm{KM}$ and project marketing, which cannot be directly examined in quantitative terms, and which therefore merits employing qualitative research methods (Denzin \& Lincoln, 2000; Miles \& Huberman, 1984). A qualitative single-case study is considered to give a rich picture and deep understanding of this less researched topic proposing directions for future research (see e.g. Woodside \& Wilson, 2003; Yin, 1994). Furthermore, the holistic view and deeper understanding enabled by case study research enhances theory-building efforts (Bonoma, 1985; Eisenhardt, 1989). In the selected case the phenomenon's relation to the context makes it especially interesting (Johnston, Leach \& Liu, 1999). The selected case project is considered to represent KM and project marketing issues in a unique way. Firstly, the case project was challenging for the selling firm due to the innovative concept and the technically less knowledgeable but very demanding customer. Secondly, the solutions offered by the selling firm are considered knowledge intensive in general. Thirdly, the case firm found that their experiences with this project provided valuable lessons on how to convince and keep the customer committed during demanding negotiations. All of these points highlight the importance of project marketing activities and provide reflections on $\mathrm{KM}$. 
The data was gathered as a part of two-year research project of a coalition that included several research institutes and company participants. Neither the identities of the informants nor of the case firm are revealed for reasons of confidentiality. The main source of data was semi-structured in-depth interviews (e.g. Arksey \& Knight, 1999) of employees of the case firm (Table 3).

(Take in: Table 3 Data sources of the case study.)

Interviewees from different functions were chosen based on the recommendations of the firm's contact persons. Interviewees held senior positions in the firm, which improved the validity of their insights about the firm. Interviewees were asked about the progress of the case project and general firm level issues on $\mathrm{KM}$ to acquire a comprehensive picture of the case. Other data sources were memos from workshops and meetings with the company, which were utilized in order to gain understanding of the case project, the firm, and the special characteristics of its business environment. In addition, the authors also used news articles, brochures, industry reports, the firm's web pages, and company documents such as e-mails, memos, minutes of meetings, internal presentations, and database snapshots to triangulate the interview and meeting data as suggested in the literature (Patton, 1987; Stake, 1995; Yin, 1994). Clarification of conflicting data was requested from interviewees by e-mail afterwards.

During the latter interviews, answers began to be repeated and no significant new information about the project was obtained, which implied an appropriate level of data saturation. All interviews were taped, transcribed and analyzed accordingly. Qualitative data analysis was employed in order to thematize the material (Miles \& Huberman, 1984) based on project marketing activities in the buyer-seller relationship and KM. The authors presented the 
proceeding of the case project in the form of a case story, which is a common form of case reporting (Yin, 1994). Based on the analyses, the conclusions were drawn on the links between KM and project marketing activities.

\section{Convincing a technically less knowledgeable customer to purchase innovative process technology}

Presenting the case project-tender preparation for an innovative solution for a large-scale investment project

The purpose of this case is to illustrate how the seller providing a complex, customized, and knowledge-intensive innovative process solution utilizes its knowledge to keep the customer interested, committed, and satisfied during the project phases. The situation requires more effort due to the buyer being less knowledgeable about the related technologies. The view on the project is retrospective, and the period of interest concerns mainly the phase of tender preparation including activities from the tender negotiations until the buyer signed the contract (Cova \& Salle, 2007). The underlying firm is one of the leading global providers of process industry technologies. Its offerings cover the whole process chain from raw material to refined end product. It can provide large turnkey solutions, technology packages or just certain stand-alone process equipment. The firm has a strong base of patented proprietary technologies and they enjoy a reputation as an innovative and experienced technology provider due to their long history in this business. 
The case project is analyzed among context, content, and process (Pettigrew, 1985; Pettigrew, 1990; Skaates \& Tikkanen, 2003). The examined context of the case project can be described as traditional industrial business, which is quite conservative in nature so that most companies do not want to be the first to adopt new technologies. Previous deliveries of similar types of process solutions are important references and work towards convincing buyer candidates. Tests and demonstrations are natural ways to remove uncertainty from new technologies, but they are expensive and time consuming. The case firm has special laboratory facilities where comprehensive analysis, research, pilots, and demonstrations can be conducted. The potential buyers often visit the facility. The content of the case is a sales project of a new, innovative, and not previously proof-tested process solution developed during the project to solve the customer's problem. In this case the solution (e.g. Cova \& Salle, 2007) refers to the design and implementation of a process technology package that was delivered as a part of a largescale investment project. The situation was uncommon in the sense that the ownership of the site where the process solution was targeted changed. Therefore, when the negotiations on the tender started between the final buyer and the seller, there was already a well-developed proposal for a technological solution. The solution is technologically new and highly new to market (Brentani, 2001), which means that both market and technological uncertainties are high for the buyer and the seller (Moriarty \& Kosnik, 1989). The described process in the case is the chain of activities and events during the tender preparations examined from project marketing and KM perspectives.

The buyer is a large global firm, which did not have deep enough technical knowledge to evaluate the offered solution, and therefore hired consultants to provide technical help and to evaluate and validate the feasibility of the offered solution. Naturally, this created an additional layer between the seller and the buyer and increased the complexity of the 
relationship. The buyer questioned the concept, and the seller found negotiating with and convincing the buyer to be an exceptionally challenging part of the project. It took a whole year before the contract was signed between the parties. The key issue in overcoming this challenge was to communicate the firm's core and project-specific knowledge on technologies and the needs of the customer to the buyer. Now the phases of the project (Table 4) will be described in more detail.

(Take in: Table 4 Case project phases and main activities.)

\section{Project negotiations before the acquisition}

Before the buyer and the seller had their first technical meeting together, the buyer had sent to the seller a list of potential risks and other critical concerns they saw with the proposed technical solution and the project they intended to buy. The project included many new solutions including for example materials and a remarkable scale up compared to previous corresponding solutions. The technical experts, sales and project personnel attended the first meeting from the seller's side. As the buyer was quite inexperienced with the field of technology they had hired consultants to provide support during the negotiations. Most of the risks and concerns were carefully answered by the seller and there did not seem to be major obstacles involved.

After the meeting the buyer announced that more negotiations were needed on the scope of the project, technical issues, and the terms under which it could proceed. The buyer wanted to have a peer-to-peer review meeting where the experts from both sides could properly discuss technical and other project related issues. Preliminary contract drafts had already been 
prepared but were not taken further due to the aforementioned reasons. Nevertheless, some engineering work was started in order to keep up with the project's main schedule. The buyer was trying to bring solution concepts from competitors to the project discussion to keep up the competition.

Negotiations on the project scope and the innovative technical solution

After these negotiations the buyer completed its planned acquisition of the project company, originally established to implement the investment project in situ, and thus became strongly involved with the case project. A four-day peer-to-peer review meeting was organized with all the technical experts, process and equipment engineers, sales, and project management. From the buyer's side there were also technical consultants, financers, and banking consultants. The seller's side was missing their most sales-oriented and experienced negotiators at the meeting. This resulted in an unbalanced negotiation situation, but the buyer emerged with a competent understanding of the seller's knowledge level. Afterwards this meeting was considered a critical stage of the project. The customer presented many hundreds of technical and project related questions which the seller later answered in writing. The new technical process solution was agreed upon in principle, but the buyer required more testing on the performance of critical equipment that had some uncertainties due to its innovativeness. Testing naturally also meant increased costs and possible delays in the schedule. As a result, the performance of the critical equipment was actually improved, and the proposed process solution concept was completed.

At this phase the buyer made a visit to a reference process facility that had similar elements to the proposed and developed solution. As it turned out, the buyer's consultants discovered 
certain flaws from the facility and used them against the seller. Actually, the seller already knew about and was dealing with those flaws. It took time and resources to invalidate the claims, but conflict was eventually avoided as both the customer and the seller handled the reference visit report with care. The lesson for the seller was that references can be counterproductive if the buyer does not receive enough knowledge about what is going on in the reference site.

Preliminary engineering work was completed at that time and a new higher project cost estimate based on the design changes was presented to the buyer. As a result, the buyer wanted to hire a consultant group again to investigate the proposed technical solution, and threatened that they might not use the developed equipment concept after all. Hence, at this stage it can be seen that the buyer was not yet committed to the proposed solution. A new design review meeting that lasted several days was organized concerning the unsolved technical issues of a mathematical model of the piece of equipment in question. According to their own calculations, the buyer's consultants were certain that the process unit would not work in practice. The consultants were invited to visit the seller's research laboratory, where the seller demonstrated the proposed solution to the consultants through simulations and demonstrations. Finally the consultants confirmed that they trusted the solution, after which the buyer was also willing to accept it.

\section{Contract negotiations}

After the agreement on the technical solution was reached, the buyer attempted to lower the price. That again required strong efforts on the seller's behalf to convince and justify its solution. As a result of these negotiations, some standard equipment was dropped out of the 
contract. The project was traveling ahead despite the fact that contract negotiations were still taking place. The contract negotiations were delayed for many reasons. Negotiations concerning discussions on process performance warranties and how to measure them were considered challenging. The buyer had hired an external law firm to take care of the contract negotiations and the buyer and the project organization had some restructuring activities that caused delay in forwarding comments on contract drafts between the parties.

\section{Discussion}

Project marketing activities utilizing core and project-specific technical and customer knowledge

Overall, the seller felt that the customer was pressuring and questioning them exceptionally hard. The customer's consultants were experts in the field and the seller really had to prove to the customer the superiority of its technical solution: "We learned a lot about arguing, because we really had to calculate and think through, why we are better than the competitor. We have always claimed that, but it has been more gut-based." The seller had not previously sold such broad process solutions in that particular field of technology, and the customer's criticism forced it to test the solution they had thought to be ready, but several crucial areas where improvements could be made were found. They were pioneering in this technology. Thus, in addition to project-specific customer knowledge new technical knowledge, both core and project-specific, was created in the project. Important procedural knowledge was created concerning how to externalize (see Nonaka, 1994) tacit technical knowledge and 
communicate it in an explicit form to the customer. The seller engaged in many kinds of project marketing activities during the examined period (Table 5).

(Take in: Table 5 Marketing activities in the case in relation to knowledge types and means of convincing.)

The seller had to convince the customer of its core technical knowledge and that it was capable of solving the customer's problem. The good reputation of the seller as a technology provider can be considered as one more passive convincing element in addition to its conclusive lists of reference projects. There was not a totally corresponding working reference facility for this project due to its innovativeness, and the reference site visit was not very successful from the seller's perspective at first. However, this illustrates that references must be systematically managed so that they can be used successfully for project marketing and to show the core knowledge of the firm in practice (Salminen, 2001).

The written answers to the presented technical questions were another element of convincing and externalizing the core and also project-specific technical knowledge. Sales and marketing people, as well as project management, played a major role in negotiating and taking care of the customer relationship. All interaction between the parties implicitly forms the impression of the knowledge levels of the parties, and so all meetings and discussions are means of project marketing to convince the customer. In project selling firms the marketing approach is inevitably focused on the technical dimensions of the offer (Cova \& Salle, 2007). Technical experts played an important role when convincing the customer and its consultants about the solution. They had to externalize and communicate the core technological knowledge that they had and that was considered as a challenge: "It is a common dilemma for us: How we can 
articulate our knowledge into a form which leads the customer to think they should buy it?" Thus, project marketing does not only concern the marketing function of a firm (Athaide et al., 1996), but it has long been a practice managed by professionally mature and marketsensitive engineers (Günter \& Bonaccorsi, 1996). However, engineers might see this as a time consuming extra activity: "When we had to work with the project (...) at the same time it was demanded that we must spend two weeks' working hours with the bosses and prepare papers, presentations, and explanations. It does not always motivate."

Project-specific technical knowledge was created as the new innovative solution was developed. The new technical knowledge was concretized through simulations, demonstrations, and laboratory visits as there were no existing references. Laboratory demonstrations also have a role in concretizing the core technical knowledge of the firm for the customer: "Well, the research laboratory is the place where our customers are enchanted." Gaining the customer's trust on this new technical solution was an especially challenging task in the case project. The technical knowledge gap that existed between the seller and the buyer perhaps made the challenge even harder. The seller had to educate the customer on the technology and its capabilities. Due to the complexity of technological process innovations, it is usual that buyers need to be educated about potential applications before they can evaluate its appropriateness (Athaide et al., 1996; Stump et al., 2002).

Concerning project-specific customer knowledge, the seller had to get to know the customer needs thoroughly in order to be able to develop the solution for the purpose, not just to customize some previously developed technical solution. Project-specific knowledge on the parties of the customer's buying organization is considered to be important in order to be able to have an effect on the decision making of the buyer (Athaide et al., 1996), and it was also 
crucial in this case. The seller had to get to know the customer's consultants too. When the seller knew the background of some of the consultants who were especially critical, it helped the seller to understand their motives and drives. One interviewee explained the critical behavior of a consultant this way: "Our customer had hired this consultant, who had previously worked for our competitor, for a very long time, and he had not forgotten his role."

Preliminary framework for utilizing KM in project marketing planning and implementation

Based on the presented literature and the case, the issues concerning utilization of KM as a tool to achieve project marketing aims in different project marketing phases are summarized in Table 6. The building blocks of the summary are the KM process perspective, knowledge categorization as core and project-specific, and the appropriate project marketing activities of different project phases identified in the literature and the case.

(Take in: Table 6 Project phases, KM strategy, and related marketing activities.)

Before a potential project is identified a firm naturally investigates and scans the market for potential new projects. The aim of project marketing is therefore to create and develop interest among potential customers. It is suggested the seller could utilize concretization and communication of core knowledge of customers and technologies in its project marketing in order to show its capability as a technology provider.

In the pre-tender phase the task of project marketing is basically the same, but there are already potential projects on which the seller considers whether to bid or not. With the help of 
reference site visits, demonstrations, and trials, the knowledge of the firm can take concrete forms, but costs must be considered against gained benefits especially at this phase. References should be selected carefully and the reference site visits should be well managed (Salminen, 2001). If the customer is technically less knowledgeable, customer education is needed first so that the customer can fully understand and evaluate the firm and its offerings. For the seller customer education provides an opportunity to get to know the customer's personnel, their needs and key decision makers. This kind of project-specific customer knowledge creation is essential for increasing the customer's interest and trust, and it can be utilized for tender preparation. Thus, it is suggested that in the pre-tender phase project marketing should aim to raise and build customer interest and trust by concretization and communication of core knowledge, and by creation and utilization of project-specific customer and technical knowledge.

In tender preparation, the aim is to utilize core and project-specific knowledge in a detailed way to meet the customer needs. Though creation of project-specific knowledge might seem an inefficient use of resources from the seller's perspective, it is still the core part of project business when customization is needed. The seller must get to know the decision makers and important stakeholders of the buyer and understand their roles during the bidding process. Creation of an adequate level of project-specific knowledge usually requires several meetings and negotiations with the customer, especially when the customer's needs and wishes are unique. Reference site visits, laboratory tests and demonstrations, trials, and customer education are also relevant at this phase, but they must be oriented towards showing that the seller can satisfy the specific needs of the customer. Comparisons and benchmarks to other competitive technical solutions and concretization of the benefits with the offered solution in financial terms are ways of project marketing to communicate the advantages of the offered 
solution. Hence, during tender preparation project marketing should aim at building the customer's trust and commitment by concretization and communication of core knowledge, and by creation and utilization of specific customer and technical knowledge in order to get the customer to sign the contract.

During (and after) a project the task of project marketing is to take care of existing buyer relationships. Another issue relevant at that phase is to gather relevant knowledge from projects. In addition to project-specific knowledge, core knowledge is also created during projects for example when new technologies are developed or the project provides good lessons from customer relationship management or appropriate project marketing activities. Core knowledge created during the project should be retained for future project marketing purposes. Retention of core technical knowledge meets the challenge of externalizing tacit knowledge to be explicit (see Nonaka, 1994). A codification strategy means that tacit knowledge is transferred into an explicit, codified form, and then stored then in databases, libraries, and files on servers (Koskinen, 2004). A personification strategy means that tacit knowledge is transferred in interaction between people, but it is not in codified form at any phase (Koskinen, 2004). This refers to socialization of tacit knowledge between people (Nonaka, 1994). Personification has been found to have a strong role in projects (Adenfelt \& Lagerstöm, 2006; Brookes et al., 2006), but when possible codification is a preferable strategy for retaining core knowledge, because personification causes knowledge, and access to it, to be dependent on people and relationships. It is then suggested that during and after project implementation project marketing should target maintaining the customer's trust and commitment by retaining, utilizing and developing core knowledge especially but also relevant project-specific technical and customer knowledge. 
The case study discussed the tender preparation phase concerning the convincing of a technically less knowledgeable customer and that provided some viewpoints as to what kind of marketing activities would then be appropriate. If the customer is less knowledgeable, it does not mean that it is also less demanding, as the case showed. It was found that in that situation the customer needs many kinds of supporting activities in order to build understanding of the offering. Actually, a knowledgeable customer is often considered to require less marketing efforts, as they know what they need and they understand what is offered (Athaide et al., 1996). It can be concluded that if the customer is technically less knowledgeable and the project is technically innovative, externalization of tacit technical knowledge requires concretization and then constant communication through several types of project marketing activities.

The presented theory and the in-depth case study combined has led to these preliminary insights on how to utilize $\mathrm{KM}$ as a tool to find appropriate project marketing activities in different project phases. It seems that knowledge types are linked to certain types of marketing activities and phases, and that $\mathrm{KM}$ can support the implementation of project marketing aims. That leads us to suggest that $K M$ is a pertinent tool to improve the appropriateness of project marketing activities, as it helps to understand knowledge types and their utilization in project marketing in different project phases.

\section{Conclusions, implications and directions for future research}

This paper examined the links between the KM process and project marketing activities in different project marketing phases. It seems that KM should be considered an important enabler of appropriate project marketing, as it helps to understand knowledge categories in 
projects and their effective use. Therefore it is suggested that KM and project marketing are strongly linked and this link should be more closely examined, because KM could be better utilized as a tool for project marketing in building customer's commitment and trust. A customer is committed when it believes in a firm's capability to succeed with the project. Especially when the customer is not technically capable of evaluating the offering, the knowledge and capabilities of the seller must be concretized and communicated carefully in many appropriate ways in different phases of the project in order to bridge the knowledge gap.

The study has implications for project marketing managers. Firstly, project marketing activities could be analyzed in terms of what they actually communicate about the firm's knowledge and capabilities for the customer. Which kind of marketing activities are appropriate in different situations can then be evaluated. Secondly, project-specific customer knowledge creation may be one-off, but it is an essential way to acquire deep understanding of customer needs and to succeed in project business. Customer education, training, and all communication are not only a way to communicate about the firm to the customer, but they should be utilized as a way to create customer knowledge. Thirdly, person-dependence of knowledge transfer in projects should be challenged by gathering knowledge from projects in a more organized way. Codification instead of personification of knowledge is encouraged (Disterer, 2002). Gathering and retaining knowledge on experiences of reference site visits and the lessons learnt would be useful for project marketing purposes. If such knowledge is not systematically retained, it is hard to systematically improve project marketing practices.

Fourthly, the need for knowledge retention suggests that systematic tools for knowledge retention, not just gathering, should be applied in project marketing. That concerns both technical and customer knowledge. The technical knowledge from prior projects, 
implemented solutions, and preferable references should be easily available. Even though codification of technical core knowledge can be challenging, the first step is to build KM infrastructures such as office libraries and databases consisting of technical documents, listings of technical problems, and best known solutions (Leseure \& Brookes, 2004). Libraries can store data on discrete facts, formatted documents, or they can be designed for effective and dynamic information sharing (Back \& Moreau, 2001). In addition to knowledge infrastructures, KM in projects can utilize creation of process models, or involving individuals into learning and social knowledge construction where knowledge is given concrete forms in roadmaps and workshops (Leseure \& Brookes, 2004). Buyer-seller relationships and the knowledge of them are often person dependent. However, customer relationship management (CRM) systems can be used to build customer knowledge of interactions between the seller and the buyer during the project and to retain that knowledge in a codified form for project marketing purposes (Zablah, Bellenger \& Johnston, 2004). For instance, people involved, lists and memos of meetings, and implemented marketing activities could be included. The difficulty here is that quite often people lack time and motivation to do this kind of documenting. The key is to involve users in designing the CRM systems so that they find it supportive in their work and the expectations regarding the system usage and benefits are more accurate and realistic (Avlonitis \& Panagopoulos, 2005).

This study has some limitations which have to be taken into account when considering its implications. The choice of a single case undoubtedly influences the ability to generalize the findings (Eisenhardt, 1989). The selection of interviewees on the basis of recommendations of the firm's contact people can affect data validity, as perhaps some important people were left out. Adding more cases could also have provided more information to back-up the insights. However, the study does not aim at a statistical generalization based on hypothesis testing, but 
provides a source of theory building (Eisenhardt, 1989) in the form of explorative ideas that can be tested later.

This study contributes to project marketing literature by providing a preliminary view on how to utilize a KM perspective in project marketing and also by providing many opportunities for future research. Firstly, future studies could continue to explore the presented insights, considering how KM can be utilized to support the aims of project marketing in project phases. Secondly, it would be important to understand the costs of marketing activities versus their effectiveness in attracting customers. Concretization of core knowledge with demonstrations, pilots, and tests is especially expensive and time consuming in a case involving process technology, so it is important to examine cost-effective ways to support it. Thirdly, the case study identified the same problem as the previous research in transferring experiences and knowledge from projects to the permanent organization (Disterer, 2002). In addition to the discontinuous nature of projects, the dependence of knowledge transfer on specific people is an oft acknowledged dilemma (Adenfelt \& Lagerstöm, 2006; Brookes et al., 2006), which makes systematic project KM demanding. Finally, a topic for future project marketing studies could be to examine how the fragmented knowledge in different organizational units is gathered so that it can be utilized in project marketing.

\section{Acknowledgements}

The useful comments of the reviewers and the financial support of the Finnish Funding Agency for Technology and Innovation are gratefully acknowledged. 


\section{References}

Adenfelt, M., \& Lagerström, K. (2006). Enabling knowledge creation and sharing in transnational projects. International Journal of Project Management, 24 (3), 191-198. Argote, L., McEvily, B., \& Reagans, R. (2003). Managing knowledge in organizations: an integrative framework and review of emerging themes. Management Science, 49 (4), 571-582. Argotea, L., \& Ingramb, P. (2000). Knowledge transfer: a basis for competitive advantage in firms. Organizational Behavior and Human Decision Processes, 82 (1), 150-169.

Arksey, H., \& Knight, P. Interviewing for Social Scientists.Sage Publications, London, 1999. Assudani, R.H. (2005). Catching the chameleon: understanding the elusive term "knowledge". Journal of Knowledge Management, 9 (2), 31-44.

Athaide, G.A., \& Stump, R. L. (1999). A taxonomy of relationship approaches during product development in technology-based, industrial markets. Journal of Product Innovation Management, 16 (5), 469-482.

Athaide, G.A., Meyers, P.W., \& Wilemon, D.L. (1996). Seller-buyer interactions during the commercialization of technological process innovations. Journal of Product Innovation Management, 13 (5), 406-421.

Athaide, G.A., Stump, R.L., \& Joshi, A.W. (2003). Understanding new product codevelopment relationships in technology-based, industrial markets. Journal of Marketing Theory and Practice, 11 (3), 46-58.

Avlonitis, G.J., \& Panagopoulos, N.G. (2005). Antecedents and consequences of CRM technology acceptance in the sales force. Industrial Marketing Management, 34 (4), 355-368. Back, W.E., \& Moreau, K.A. (2001). Information management strategies for project management. Project Management Journal, 32 (1), 10-19.

Backhaus, K. Investitionsgütermarketing (4th ed.). Vahlen, München, 1995. 
Bonoma, T.V. (1985). Case research in marketing: opportunities, problems, and a process. Journal of Marketing, 22 (2), 199-208.

Boughton, P. (1987). The competitive bidding process: beyond probability models. Industrial Marketing Management, 16 (2), 87-94.

Brentani, U. (2001). Innovative versus incremental new business services: different keys for achieving success. Journal of Product Innovation Management, 18 (1), 169-187.

Bresnen, M., Edelman, L., Newell, S., Scarbrough, H., \& Swan, J. (2003). Social practices and the management of knowledge in project environments. International Journal of Project Management, 21 (3), 157-166.

Brookes, N.J., Morton, S.C., Dainty, J.A., \& Burns, N.D. (2006). Social processes, patterns and practices and project knowledge management: a theoretical framework and empirical investigation. International Journal of Project Management, 24 (6), 474-482.

Cohen, W.M., \& Levinthal, D.A. (1990). Absorbtive capacity: a new perspective on learning and innovation. Administrative Science Quarterly, 35 (1), 128-152.

Cova, B., \& Ghauri, P.N. (1996). Project marketing. Between mass marketing and networks. European Seminar on Project Marketing and Systems Selling.

Cova, B., \& Holstius, K. (1993). How to create competitive advantage in project business. Journal of Marketing Management, 9 (2), 105-121.

Cova, B., \& Hoskins, S. (1997). A twin-track networking approach to project marketing. European Management Journal, 15 (5), 546-556.

Cova, B., \& Salle, R. (2007). Introduction to the IMM special issue on 'project marketing and the marketing of solutions' a comprehensive approach to project parketing and the marketing of solutions. Industrial Marketing Management, 36 (2), 138-146.

Cova, B., Ghauri, P., \& Salle, R. Project Marketing - Beyond Competitive Bidding. John Wiley \& Sons, Chichester, 2002. 
Cova, B., Mazet, F., \& Salle, R. (1996). Milieu as a perninent unit of analysis in project marketing. International Business Review, 5 (6), 647-664.

Denzin, N.K., \& Lincoln, Y.S. Introduction: the discipline and practice of qualitative research, in Handbook of Qualitative Research (2nd ed.), N. K. Denzin, \& Y. S. Lincoln, eds., Sage Publications, Thousand Oaks, 2000.

Disterer, G. (2002). Management of project knowledge and experiences. Journal of Knowledge Management, 6 (5), 512-520.

Eisenhardt, K.M. (1989). Building theories from case study research. Academy of Management Review, 14 (4), 532-550.

Galbraith, J.R. Designing the Customer-Centric Organization. Jossey-Bass, San Francisco, 2005.

Gulati, R. (1995). Does familiarity breed trust? The implications of repeated ties for contractual choice in alliances. Academy of Management Journal, 38 (1), 85-112.

Günter, B., \& Bonaccorsi, A. (1996). Project marketing and systems selling - in search of frameworks and insights. International Business Review, 5 (6), 531-537.

Hadjikhani, A. (1996). Project marketing and the management of discontinuity. International Business Review, 5 (3), 319-336.

Hänninen, S., \& Kauranen, I. (2007). Product innovation as micro strategy. International Journal of Innovation and Learning, 4 (4), 425-443.

Johnston, W.J., Leach, M.P., \& Liu, A.H. (1999). Theory testing using case studies in business-to-business research. Industrial Marketing Management, 28 (3), 201-213. Kakabadse, N.K., Kakabadse, A., \& Kouzmin, L. (2003). Reviewing the knowledge management literature: towards a taxonomy. Journal of Knowledge Management, 7 (4), 75-91. 
Kasvi, J.J., Vartiainen, M., \& Hailikari, M. (2003). Managing knowledge and knowledge competences in projects and project organisations. International Journal of Project Management, 21 (8), 571-582.

Koskinen, K.U. (2004). Knowledge management to improve project communication and implementation. Project Management Journal, 35 (2), 13-19.

Leseure, M.J., \& Brookes, N.J. (2004). Knowledge management benchmarks for project management. Journal of Knowledge Management, 8 (1), 103-116.

Leybourne, S.A. (2007). The changing bias of project management research: a consideraton of the literatures and an application of extant theory. Project Management Journal, 38 (1), 6173.

Mattsson, L.G. (1973). Systems selling as a strategy on industrial markets. Industrial Marketing Management, 3 (2), 107-120.

Meyers, P.W., \& Athaide, G.A. (1991). Strategic mutual learning between producing and buying firms during product innovation. Journal of Product Innovation Management, 8 (3), 155-169.

Miles, M., \& Huberman, M. Qualitative Data Analysis: A Source Book of New Methods. Sage Publications, California, Newbury Park, 1984.

Moriarty, R., \& Kosnik, T. (1989). High tech marketing: concept, continuity and change. Sloan Management Review, 30 (4), 7-17.

Nonaka, I. (1994). A dynamic theory of organizational knowledge creation. Organization Science, 5 (1), 14-37.

Nonaka, I., \& Takeuchi, H. The Knowledeg-Creating Company. How Japanese Companies Create the Dynamics of Innovation. Oxford University Press, New York, 1995.

Patton, M. Q. Qualitative Evaluation and Research Methods. Sage Publications, California, 1987. 
Pettigrew, A.M. Context, culture and politics. The development of strategic change, in The Awakening Giant, A.M. Pettigrew, ed., Blackwell, Oxford, 1985.

Pettigrew, A.M. (1990). Longitudinal field research on change: theory and practice.

Organization Science, 1 (3), 267-292.

Polanyi, M. The Tacit Dimension. Routledge and Kegan Paul, London, 1966

Probst, G., Raub, S., \& Romhardt, K. Managing Knowledge: Building Blocks for Success. John Wiley \& Sons, Chichester, 2000.

Reich, B.H. (2007). Managing knowledge and learning in IT projects: a conceptual framework and guidelines for practice. Project Management Journal, 38 (2), 5-17.

Salminen, R.T. (2001). Success factors of a reference visit - a single case study. Journal of Business \& Industrial Marketing, 16 (6/7), 487-507.

Skaates, M.A., \& Tikkanen, H. (2003). International project marketing: an introduction to the INPM approach. International Journal of Project Management, 21 (7), 503-510.

Skaates, M.A., Tikkanen, H., \& Alajoutsijärvi, K. (2003). The international marketing of professional service projects: to what extent does territoriality matter? The Journal of Services Marketing, 17 (1), 83-97.

Skaates, M.A., Tikkanen, H., \& Lindblom, J. (2002). Relationships and project marketing success. The Journal of Business \& Industrial Marketing, 17 (5), 389-406.

Snider, K.F., \& Nissen, M.E. (2003). Beyond the body of knowledge: a knowledge-flow approach to project management theory and practice. Project Management Journal, 34 (2), 411.

Stake, R.E. The Art of Doing Case Study Research. Sage Publications, California, Thousand Oaks, 1995.

Stanko, M.A., Bonner, J. M., \& Calantone, R. J. (2007). Building commitment in buyer-seller relationships: a tie strength perspective. Industrial Marketing Management, 36 (8), 1094-1103. 
Stump, R. L., Athaide, G.A., \& Joshi, A.W. (2002). Managing seller-buyer new product development relationships for customized products: a contingency model based on transaction cost analysis and empirical test. Journal of Product Innovation Management, 19 (6), 439-454. Tikkanen, H. (1998). Research on international project marketing. A review and implications. In H. Tikkanen, Essays in Honour of Professor Karin Holstius on her 65th Birthday. Turku: Turku School of Economics and Business Administration.

Verworn, B. (2006). How german measurement and control firms integrate market and technological knowledge into the front end of new product development. International Journal of Technology Management, 34 (3-4), 379-389.

Woodside, A.G., \& Wilson, E.J. (2003). Case study research methods for theory building. Journal of Business \& Industrial Marketing, 18 (6/7), 493-508.

Yin, R.K. Case Study Research (2nd Edition ed.). Sage Publications, California, Thousand Oaks, 1994.

Zablah, A.R., Bellenger, D.N., Johnston, W.J. (2004). An evaluation of divergent perspectives on customer relationship management: towards a common understanding of an emerging phenomenon. Industrial Marketing Management, 33 (6), 475-489. 


\section{Tables and figures}

Table 1 Marketing activities in a buyer-seller relationship (Athaide et al., 1996).

\begin{tabular}{|l|l|}
\hline Marketing activity & Explanation \\
\hline Product customization & $\begin{array}{l}\text { Customization to customer's requirements, co-design, modifications prior } \\
\text { to installation, co-development, consistent cooperation with the customer } \\
\text { to solve product problems } \\
\text { Searching input for product modifications, additional product features, } \\
\text { problems with the product, product design, and features } \\
\text { Indicating which tasks would change after buying the product and how it } \\
\text { product performance } \\
\text { Product education/training } \\
\text { functionalities of the product; demonstrating applications of the product; } \\
\text { providing instruction manuals } \\
\text { Annual service contracts, product upgrades } \\
\text { Negotiations with different factions or interest groups in the buying } \\
\text { organization, understanding the politics of the customer's organization } \\
\text { Product demonstrations, free or low-cost trials, option to buy the product } \\
\text { Proactive political involvement } \\
\text { in stages } \\
\text { Open communication maintained with the customer, immediate answers to } \\
\text { customer problems } \\
\text { Real-time problem solving } \\
\text { assistance }\end{array}$ \\
$\begin{array}{l}\text { Clarification of the product's } \\
\text { relative advantage }\end{array}$ & \begin{tabular}{l} 
Prestation of product tests, on-site service support \\
\hline
\end{tabular}
\end{tabular}

Table 2 Knowledge categorization utilized in this study.

\begin{tabular}{|l|l|l|}
\hline & Core knowledge & Project-specific knowledge \\
\hline $\begin{array}{l}\text { Technical } \\
\text { knowledge }\end{array}$ & $\begin{array}{l}\text { Core technical knowledge } \\
\text { Essential for the firm's business as it is the basis of } \\
\text { firm's capability to deliver complex technical solutions. } \\
\text { Applicable across projects. } \\
\text { New core technical knowledge can be created in } \\
\text { projects. }\end{array}$ & $\begin{array}{l}\text { Project-specific technical knowledge } \\
\text { Created when a unique process } \\
\text { solution is developed and } \\
\text { implemented. } \\
\text { Not applicable across projects. } \\
\text { Includes technical knowledge needed } \\
\text { for the customization of the solution. }\end{array}$ \\
\hline $\begin{array}{l}\text { Customer } \\
\text { fnowledge }\end{array}$ & $\begin{array}{l}\text { Core customer knowledge } \\
\text { Essential for the firm's business } \\
\text { Applicable across projects. } \\
\text { Firm's general level of knowledge of customers' } \\
\text { characteristics in a business field and managing } \\
\text { customer relationships. } \\
\text { Includes customer needs and wishes, customer's } \\
\text { business environment, the buying center, and the } \\
\text { stakeholders. } \\
\text { New core customer knowledge can be created in } \\
\text { projects }\end{array}$ & $\begin{array}{l}\text { Project } \\
\text { Created mostly in interaction with the } \\
\text { project customer. } \\
\text { Not applicable across projects. } \\
\text { Includes knowledge of a specific } \\
\text { customer relationship, customer's } \\
\text { needs and wishes, customer's business } \\
\text { environment, the buying center, and } \\
\text { the stakeholders. }\end{array}$ \\
\hline
\end{tabular}




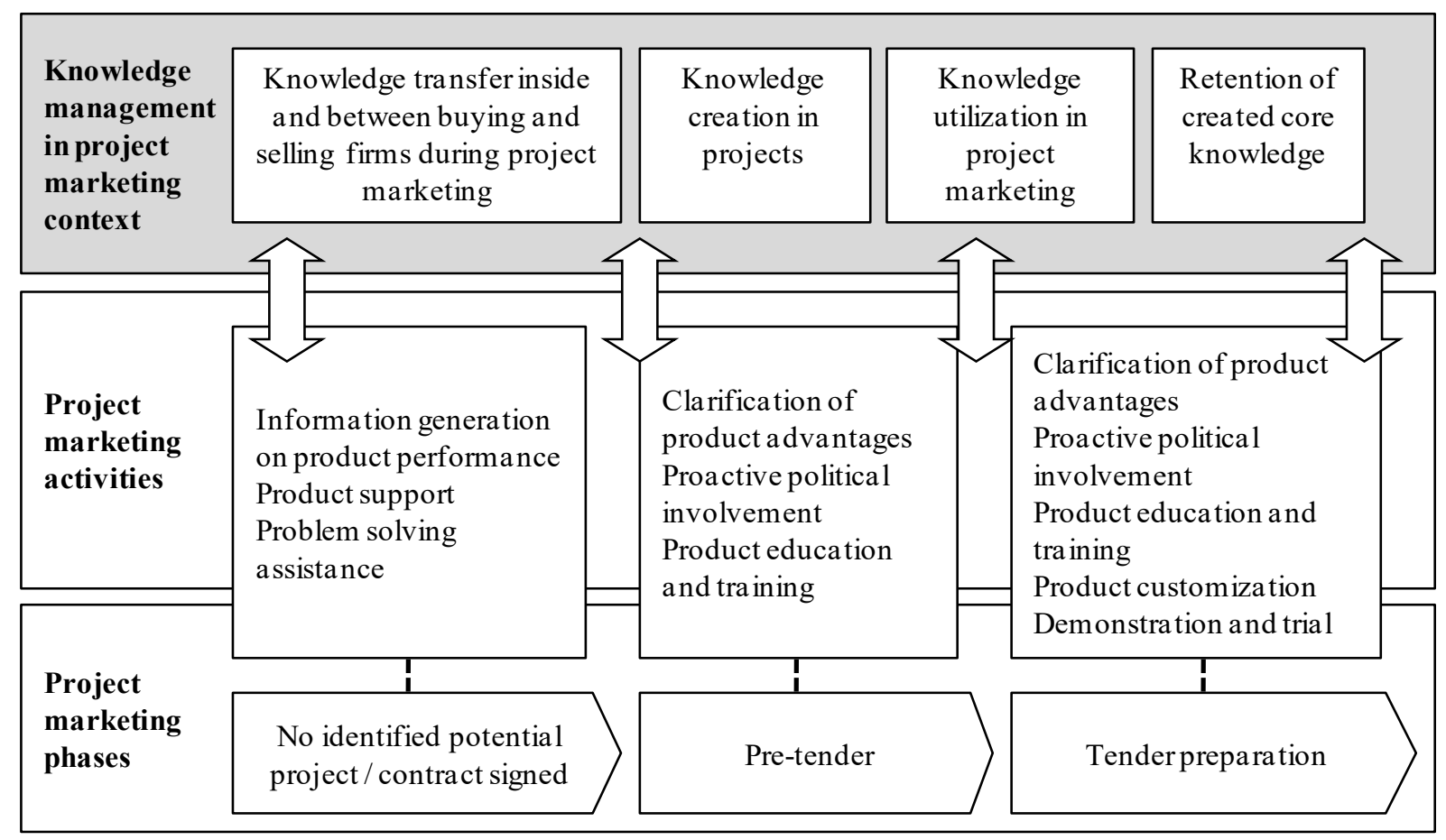

Figure 1 Linkages of KM to project marketing phases.

Table 3 Data sources of the case study.

\begin{tabular}{|l|l|}
\hline Data source (years of service of the interviewee with the firm) & Date (interview's duration) \\
\hline Technology Director (15) & September 2006 (2h) \\
Senior Technology Specialist (over 23) & October 2006 (2h) \\
VP, New Business Solutions (over 20) & October 2006 (2h) \\
VP, Sales I (over 10) & October 2006 (2h) \\
Technology Specialist (7) & October 2006 (1,5h) \\
Project Manager (26) & October 2006 (2,5h) \\
VP, Sales II (over 10) & October 2006 (1,5h) \\
Two half-day workshops and their memos & February and September 2007 \\
Five meetings with firm personnel & Fall 2006 - Spring 2008 \\
Internal firm presentations, memos, database snapshots & \\
Brochures, news, industry reports, annual reports, web pages & \\
\hline
\end{tabular}


Table 4 Case project phases and main activities.

\begin{tabular}{|l|l|l|}
\hline Before acquisition & $\begin{array}{l}\text { Negotiations on the project scope and } \\
\text { technical solution }\end{array}$ & Contract negotiations \\
\hline $\begin{array}{l}\text { List of questions from the } \\
\text { customer concerning project risks } \\
\text { (mainly operational and }\end{array}$ & $\begin{array}{l}\text { Peer review meeting: Negotiations on } \\
\text { project scope, proceedings, and technical } \\
\text { technical) }\end{array}$ & $\begin{array}{l}\text { Negotiations e.g. on price, } \\
\text { and warranties } \\
\text { Project in good progress } \\
\text { Contract negotiations }\end{array}$ \\
$\begin{array}{l}\text { The customer visits the seller } \\
\text { Customer hires consultants to } \\
\text { help to evaluate the offering }\end{array}$ & $\begin{array}{l}\text { but discussion on innovative equipment } \\
\text { continues }\end{array}$ & $\begin{array}{l}\text { More testing on the innovative equipment } \\
\text { parties being involved } \\
\text { Contract signed }\end{array}$ \\
basic engineering but requires \\
more negotiations on project \\
scope, proceedings, and technical \\
issues & in several phases & \\
Basic engineering started & Customer visits a reference site & \\
& Increased cost estimate presented to the \\
& customer & \\
New design review meeting with the & \\
& customer & \\
Agreement on the technical solution & \\
\hline
\end{tabular}

Table 5 Marketing activities in the case in relation to knowledge types and means of convincing.

\begin{tabular}{|c|c|c|}
\hline & Convincing through concretization & Convincing through interaction \\
\hline $\begin{array}{l}\text { Core } \\
\text { technical } \\
\text { knowledge }\end{array}$ & $\begin{array}{l}\text { Firm reputation (passive) } \\
\text { Lists of references (passive) } \\
\text { Laboratory visits } \\
\text { Mathematical simulations } \\
\text { Laboratory demonstrations }\end{array}$ & $\begin{array}{l}\text { Reports concerning technical and other project } \\
\text { related questions } \\
\text { All interaction: discussions, } \\
\text { meetings, negotiations } \\
\text { Informal customer education through } \\
\text { discussions and meetings }\end{array}$ \\
\hline $\begin{array}{l}\text { Project- } \\
\text { specific } \\
\text { technical } \\
\text { knowledge }\end{array}$ & $\begin{array}{l}\text { Reference site visit } \\
\text { Mathematical simulations } \\
\text { Laboratory demonstrations } \\
\text { Developing a solution for the customer need }\end{array}$ & $\begin{array}{l}\text { Presentations on solution benefits } \\
\text { Articulation of the problem and the proposed } \\
\text { technical solution }\end{array}$ \\
\hline $\begin{array}{l}\text { Project- } \\
\text { specific } \\
\text { customer } \\
\text { knowledge }\end{array}$ & Unique solution for the customer need & $\begin{array}{l}\text { Articulation of the customer needs } \\
\text { Getting to know the buying center } \\
\text { Getting to know the specific needs and } \\
\text { characteristics of the customer }\end{array}$ \\
\hline
\end{tabular}


Table 6 Project phases, KM strategy, and related marketing activities.

\begin{tabular}{|c|c|c|c|c|}
\hline $\begin{array}{c}\text { Project } \\
\text { marketing } \\
\text { phases }\end{array}$ & $\begin{array}{c}\text { No identified } \\
\text { potential project }\end{array}$ & Pre-tender & Tender preparation & After a contract \\
\hline $\begin{array}{c}\text { Aim of } \\
\text { project } \\
\text { marketing }\end{array}$ & $\begin{array}{l}\text { Raise interest } \\
\text { among potential } \\
\text { customers }\end{array}$ & $\begin{array}{l}\text { Raise customer interest } \\
\text { among potential project } \\
\text { customers and build trust } \\
\text { in firm's capabilities }\end{array}$ & $\begin{array}{l}\text { Build the customer's } \\
\text { trust on firm's } \\
\text { capabilities and get the } \\
\text { customer committed to } \\
\text { sign a contract }\end{array}$ & $\begin{array}{l}\text { Retain and } \\
\text { develop trust and } \\
\text { commitment to } \\
\text { keep up a good } \\
\text { business } \\
\text { relationship }\end{array}$ \\
\hline $\begin{array}{c}\text { KM } \\
\text { approach }\end{array}$ & $\begin{array}{l}\text { Concretize and } \\
\text { communicate } \\
\text { customer and } \\
\text { technical core } \\
\text { knowledge }\end{array}$ & $\begin{array}{l}\text { Concretize and } \\
\text { communicate customer } \\
\text { and technical core } \\
\text { knowledge } \\
\text { Create and utilize project- } \\
\text { specific technical and } \\
\text { customer knowledge }\end{array}$ & $\begin{array}{l}\text { Concretize and } \\
\text { communicate customer } \\
\text { and technical core } \\
\text { knowledge } \\
\text { Utilize and create } \\
\text { project-specific } \\
\text { technical and customer } \\
\text { knowledge }\end{array}$ & $\begin{array}{l}\text { Retain all core } \\
\text { knowledge } \\
\text { Retain and utilize } \\
\text { project-specific } \\
\text { customer } \\
\text { knowledge if not } \\
\text { a one-off project }\end{array}$ \\
\hline $\begin{array}{c}\begin{array}{c}\text { Project } \\
\text { marketing } \\
\text { activities }\end{array} \\
\frac{\text { Highlighted }}{\underline{\text { issues in this }}} \\
\underline{\text { case }}\end{array}$ & $\begin{array}{l}\text { Concretize: } \\
\text { Technical reports } \\
\text { Laboratory visits } \\
\text { Product } \\
\text { demonstration } \\
\text { and trials } \\
\text { Communicate: } \\
\text { Firm reputation } \\
\text { Lists of } \\
\text { references } \\
\text { Marketing } \\
\text { materials } \\
\text { Customer } \\
\text { education } \\
\text { Clarification of } \\
\text { product } \\
\text { advantages } \\
\text { All interaction } \\
\text { with potential } \\
\text { customers }\end{array}$ & 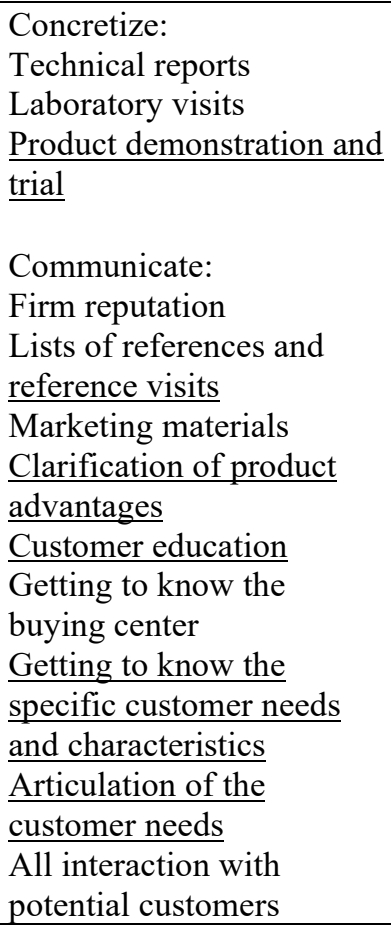 & $\begin{array}{l}\text { Concretize: } \\
\text { Product demonstration } \\
\text { and trial } \\
\text { Reference visits } \\
\text { Laboratory visits and } \\
\frac{\text { tests }}{\text { Developing a solution }} \\
\text { for the customer need } \\
\text { Communicate: } \\
\text { Clarification of product } \\
\text { advantage } \\
\text { Product education and } \\
\text { training } \\
\text { Articulation of the } \\
\text { problem and the } \\
\text { proposed solution } \\
\text { Influencing the buying } \\
\text { center } \\
\text { All interaction with } \\
\text { potential customers }\end{array}$ & $\begin{array}{l}\text { Concretize and } \\
\text { communicate: } \\
\text { Information } \\
\text { generation on } \\
\text { product } \\
\text { performance } \\
\text { Product support } \\
\text { Problem solving } \\
\text { assistance }\end{array}$ \\
\hline
\end{tabular}

